\title{
Carbon dioxide diffuse emission and thermal energy release from hydrothermal systems at Copahue-Caviahue Volcanic Complex (Argentina)
}

\author{
Giovanni Chiodini ${ }^{a}$, Carlo Cardellini ${ }^{\mathrm{b}}$, María Clara Lamberti ${ }^{\mathrm{c}, *}$, Mariano Agusto $^{\mathrm{c}}$, Alberto Caselli ${ }^{\mathrm{d}}$, \\ Caterina Liccioli ${ }^{\mathrm{c}}$, Giancarlo Tamburello ${ }^{\mathrm{e}}$, Franco Tassi ${ }^{\mathrm{f}, \mathrm{g}}$, Orlando Vaselli ${ }^{\mathrm{f} g}$, Stefano Caliro ${ }^{\mathrm{h}}$ \\ a Istituto Nazionale di Geofisica e Vulcanologia, Sezione di Bologna, Via D. Creti 12, 40128 Bologna, Italy \\ ${ }^{\mathrm{b}}$ Università degli Studi di Perugia, Dipartimento di Fisica e Geologia, Via G. Pascoli snc, I-06123 Perugia, Italy \\ c IDEAN-GESVA, Dpto. Cs. Geológicas, FCEN, Universidad de Buenos Aires, Buenos Aires, Argentina \\ d LESVA-IIPG. Universidad Nacional de Río Negro, General Roca, Argentina \\ e Università degli Studi di Palermo, DiSTeM, Via Archirafi 36, I-90123 Palermo, Italy \\ ${ }^{\mathrm{f}}$ Università degli Studi di Firenze, Dipartimento di Scienze della Terra, Via G La Pira 4, I-50121 Firenze, Italy \\ ${ }^{g}$ Istituto di Geoscience e Georisorse-Consiglio Nazionale delle Ricerche (CNR-IGG), Via La Pira, 4, I-50121, Firenze, Italy \\ ${ }^{\text {h }}$ Istituto Nazionale di Geofisica e Vulcanologia, Sezione di Napoli-Osservatorio Vesuviano, Via Diocleziano 328, I-80124 Napoli, Italy
}

\section{A R T I C L E I N F O}

\section{Article history:}

Received 30 April 2015

Accepted 2 September 2015

Available online 10 September 2015

\section{Keywords:}

Caviahue Caldera

Copahue Volcano $\mathrm{CO}_{2}$ diffuse degasing

Thermal energy

\begin{abstract}
A B S T R A C T
The north-western sector of Caviahue caldera (Argentina), close to the active volcanic system of Copahue, is characterized by the presence of several hydrothermal sites that host numerous fumarolic emissions, anomalous soil diffuse degassing of $\mathrm{CO}_{2}$ and hot soils. In March 2014, measurements of soil $\mathrm{CO}_{2}$ fluxes in 5 of these sites (namely, Las Máquinas, Las Maquinitas I, Las Maquinitas II, Anfiteatro, and Termas de Copahue) allowed an estimation that $\sim 165 \mathrm{t}$ of deeply derived $\mathrm{CO}_{2}$ is daily released. The gas source is likely related to a relatively shallow geothermal reservoir containing a single vapor phase as also suggested by both the geochemical data from the 3 deep wells drilled in the 1980s and gas geoindicators applied to the fumarolic discharges. Gas equilibria within the $\mathrm{H}-\mathrm{C}-\mathrm{O}$ gas system indicate the presence of a large, probably unique, single phase vapor zone at $200-210^{\circ} \mathrm{C}$ feeding the hydrothermal manifestations of Las Máquinas, Las Maquinitas I and II and Termas de Copahue. A natural thermal release of $107 \mathrm{MW}$ was computed by using $\mathrm{CO}_{2}$ as a tracer of the original vapor phase. The magmatic signature of the incondensable fumarolic gases, the wide expanse of the hydrothermal areas and the remarkable high amount of gas and heat released by fluid expulsion seem to be compatible with an active magmatic intrusion beneath this portion of the Caviahue caldera.
\end{abstract}

(C) 2015 Elsevier B.V. All rights reserved.

\section{Introduction}

The poor knowledge of $\mathrm{CO}_{2}$ fluxes released from natural sources, such as mantle and metamorphic reactions, is one of the most vexing problems in understanding the geological carbon cycle (Berner and Lasaga, 1989). Large uncertainties affect the estimates of global $\mathrm{CO}_{2}$ flux from volcanoes (Burton et al., 2013 and reference therein) due to the relatively limited flux measurements of volcanic plumes from persistently degassing volcanoes. In addition, the amount of $\mathrm{CO}_{2}$ not directly related to volcanic craters and released from hydrothermal systems associated with most active volcanic regions is poorly constrained. Recently, an international initiative to fill this gap has been promoted by the scientific community with a project named DECADE (https://deepcarbon.net/ content/deep-carbon-observatory-launches-decade-initiative), which

\footnotetext{
* Corresponding author. Tel.: +54 1145763400.

E-mail address: mclamberti@gl.fcen.uba.ar (M.C. Lamberti).
}

supports investigations focused on the study of $\mathrm{CO}_{2}$ fluxes from active volcanoes. The present study is in the framework of this initiative, being aimed at mapping and quantifying deep-originated $\mathrm{CO}_{2}$, diffusively discharged from the hydrothermal areas located few kilometers east of the active volcanic system of Copahue (Patagonia, Argentina), where fumarolic discharges and large zones of soil diffuse gas emission occur. A second goal of this study is to provide an estimation of the local geothermal potential.

The development of a quick and reliable technique for the measurements of soil $\mathrm{CO}_{2}$ fluxes (Chiodini et al., 1998) has recently promoted applications in different fields of geological and environmental sciences. One of the most promising applications of this tool (namely, the accumulation chamber method) regards the use of soil $\mathrm{CO}_{2}$ flux surveys for geothermal prospecting. This method allows recognizing and characterizing $\mathrm{CO}_{2}$ flux anomalies at the surface, which are caused by the circulation of hydrothermal fluids at depth. Soil $\mathrm{CO}_{2}$ fluxes higher than those due to biologic activity are indeed commonly associated with 
the circulation of hydrothermal fluids (Chiodini et al., 1998; Cardellini et al., 2003; Lewicki and Oldenburg, 2005). In addition, recent studies have shown that $\mathrm{CO}_{2}$ diffuse degassing can provide important and reliable constraints for a correct evaluation of the geothermal potential from hydrothermal areas (Chiodini et al. 2005; Fridriksson et al., 2006; Werner and Cardellini, 2006; Chiodini et al., 2007; Mazot and Taran, 2009; Hernández et al., 2012; Rissmann et al., 2012; Bloomberg et al., 2014; Granieri et al., 2014; Dionis et al., 2015). In particular, the total budget of hydrothermal gases released at the surface can be used for a robust estimation of the minimum amount of geothermal fluids involved at depth in the degassing process. Consequently, the accumulation chamber method represents an effective, rapid and cheap instrumentation for estimating the minimum geothermal potential of an unknown area since the thermal energy naturally transported and released by the fluids can be evaluated.

\section{Geological, volcanological and hydrothermal setting}

The Copahue-Caviahue Volcanic Complex (hereafter CCVC, $38^{\circ} \mathrm{S}-$ $71^{\circ} \mathrm{W}$ ) is located in the Neuquén Province (Patagonia, Argentina) on a segment of the Andes range, called the South Volcanic Zone (hereafter SVZ: $\left.33.3^{\circ}-46^{\circ} \mathrm{S}\right), 30 \mathrm{~km}$ east of the main Pleistocene-Holocene volcanic front (Fig. 1). Volcanism in the SVZ is related to the subduction of the Nazca Plate beneath the South American Plate, at rates as high as $10.8 \mathrm{~cm} \mathrm{y}^{-1}$ (DeMets et al., 1994; Ramos and Folguera, 2000; Melnick et al., 2006).

The steepening of the oceanic plate subducted in the last 5 Ma resulted in the displacement of the asthenospheric wedge and an asthenospheric upwelling. This process favored a process of crustal thinning that caused the most recent westward migration of the volcanic arc, extensional dynamics and large effusions of basaltic-andesitic magma (Folguera et al., 2006; Yuan et al., 2006).

The CCVC includes the Caviahue Caldera (also known as Caldera del Agrio), a volcano-tectonic depression defined as an intra-arc extensional pull-apart basin (Ramos and Folguera, 2000; Bermúdez et al., 2002; Melnick et al., 2006; Rojas Vera et al., 2010). The pull-apart basin is located at the transition zone between the Liquiñe-Ofqui dextral-slip and the Antiñir-Copahue fault systems (Lavenu and Cembrano, 1999; Folguera et al., 2004). The former accommodates lateral displacements imposed by the oblique convergence between the Nazca and South American plates from $\sim 46^{\circ} \mathrm{S}$ to $\sim 38^{\circ} \mathrm{S}$ (Radic, 2010). The CCVC encompasses the Copahue volcano, a Pleistocene polygenic stratovolcano located in the southwestern rim of the Caviahue Caldera, whose main products are andesites and basalts (Polanco, 2003). The easternmost of the nine NE-oriented summit craters of the Copahue volcano is currently active. During the last 250 years, at least thirteen lowmagnitude phreatic and phreatomagmatic eruptions occurred from this crater (Martini et al., 1997; Naranjo and Polanco, 2004). The 1992 and 1995 eruptions mostly consisted of phreatic events characterized by the emission of pyroclastic sulfur. In 2000, a phreatomagmatic eruption, mainly involving juvenile material, occurred (Delpino and Bermúdez, 1993, 2002; GVN, 2000a,2000b). Since November-December 2011, the discharge rate of fluids from the Copahue active crater increased, whereas sporadic phreatic events have been occurring since July 2012. A major phreatomagmatic-magmatic eruption was observed on December 22, 2012 and a significant degassing is still ongoing (Caselli et al., accepted for publication).

During quiescent periods, the active crater hosts a hot acidic lake (up to $63{ }^{\circ} \mathrm{C}$ and $\mathrm{pH}<1$ ) (Varekamp et al., 2001; Varekamp et al. 2009; Agusto, 2011; Agusto et al., 2012; 2013). Two acidic hot springs (up to $80{ }^{\circ} \mathrm{C}$ and $\mathrm{pH}=1-2$ ) discharge in the eastern summit flank of the cone and merge downstream to form the upper Agrio river $(\mathrm{pH}=2$ 3), which flows into the acidified glacial Lake Caviahue (Martini et al., 1997; Gammoms et al. 2005; Varekamp, 2008; Caselli et al., 2005; Agusto, 2011; Agusto and Varekamp 2015).

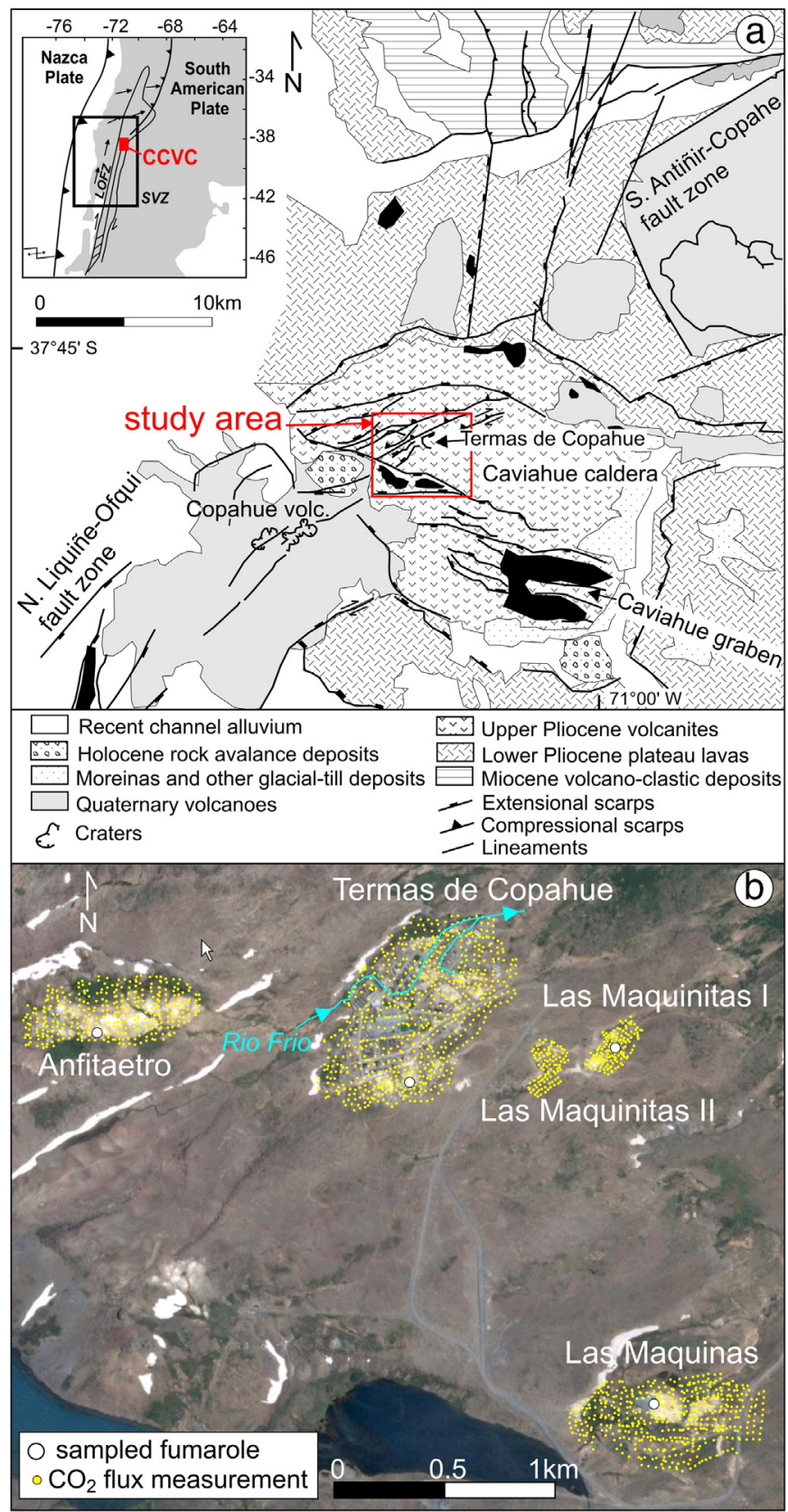

Fig. 1. a) Geological, volcanological and structural setting of the Copahue-Caviahue Volcanic Complex and location of the study area (modified from Folguera et al., 2004); b) location of the surveyed hydrothermal sites.

In March 2014, a remote sensing campaign, carried out by combining MiniDoas and Multigas techniques, revealed the presence of an important gas plume from the crater lake and allowed a rough estimation of the released $\mathrm{SO}_{2}$ and $\mathrm{CO}_{2}$, which resulted to be of $\sim 960$ and $\sim 640 \mathrm{t} \mathrm{d}^{-1}$, respectively (Tamburello et al., in press).

In the north-eastern flank of the Copahue volcanic edifice, within the Caviahue Caldera, six hydrothermal areas are recognized: Las Máquinas, Las Maquinitas I, Las Maquinitas II, Anfiteatro, Termas de Copahue and Chancho-Co (Mas et al., 1996; 2000; Fig. 1). The hydrothermal activity of some of these sites (Las Máquinas, Las Maquinitas and Termas de Copahue) is so intense that causes a background volcanic tremor as revealed by a seismic array analysis performed in the 2003-2005 period (Ibáñez et al., 2008). Fluids are discharged as boiling, bubbling and mud pools (up to temperatures of $96{ }^{\circ} \mathrm{C}$ ), fumaroles (up to $130{ }^{\circ} \mathrm{C}$ at La Maquinitas I) and large areas of diffuse degassing and hot soils. 
According to the recent, comprehensive study of the hydrothermal-volcanic fluids at CCVC by Agusto et al. (2013), the fumarole chemistry suggested that the gas source was associated with boiling processes of a hydrothermal system, mainly fed by meteoric water, although affected by magmatic fluids of mantle signature, as indicated by the relatively high ${ }^{3} \mathrm{He} /{ }^{4} \mathrm{He}$ ratios $(\mathrm{R} / \mathrm{Ra}>7)$.

\section{Material and methods}

\subsection{Sampling and analysis of gas from fumaroles}

Fumarolic discharges from the thermal areas of Las Máquinas, Las Maquinitas I and II, Termas de Copahue and Anfiteatro were collected in March 2012 by using pre-evacuated flasks containing a $4 \mathrm{~N} \mathrm{NaOH}$ solution (Giggenbach, 1975; Giggenbach and Gouguel, 1989) for the analysis of the major gas species. Vapor condensates and, separately, dry gases were sampled using a condenser, cooled at $\sim 20-30{ }^{\circ} \mathrm{C}$ by cold water. The chemical analyses were carried out at Osservatorio Vesuviano (INGV) laboratories. The gas chemistry of non-absorbed gases, present in the headspace over the $\mathrm{NaOH}$ solution, was determined by gas chromatography through a unique injection on two molecular sieve columns (MS 5 Å capillary, $30 \mathrm{~m} \times 0.53 \mathrm{~mm} \times 50 \mu \mathrm{m}$; He and $\mathrm{Ar}$ as carrier gases) using TCD detectors. Carbon dioxide and sulfur species absorbed in the alkaline solution were analyzed after oxidation via $\mathrm{H}_{2} \mathrm{O}_{2}$, by acid-base titration and ion chromatography, respectively (analytical error $\pm 3 \%$ ). Because of reaction in alkaline solution to form $\mathrm{COOH}^{-}$(Giggenbach and Matsuo, 1991), CO was analyzed on dry gas samples by gas chromatographic separation with a MS $5 \AA 1 / 8 \times 50$ in column (He as carrier gas) coupled with a high-sensitivity Reduced Gas Detector $(\mathrm{HgO})$. The analytical results are reported in Table 1. In the Table 1 the ${ }^{3} \mathrm{He} /{ }^{4} \mathrm{He}$ isotopic ratios, expressed as $\mathrm{R} / \mathrm{Ra}$ where $\mathrm{R}$ is the measured ${ }^{3} \mathrm{He} /{ }^{4} \mathrm{He}$ ratio and $\mathrm{Ra}$ is that of air $\left(1.39 \times 10^{-6}\right)$, are from Agusto et al. (2013).

\subsection{Fumarolic flux}

A well defined gas plume, suitable for the determination of the $\mathrm{CO}_{2}$ flux discharged by the fumarolic vent, was found at Las Maquinitas I. Here, the technique proposed by Aiuppa et al. (2013) was applied. The method consists on the measurement of the Integrated Column Amount (ICA, $\mathrm{kg} \mathrm{m}^{-1}$ ) of $\mathrm{CO}_{2}$ that is subsequently multiplied by the plume transport speed $(\mathrm{m} / \mathrm{s})$ to calculate the flux. The concentration in the plume of $\mathrm{CO}_{2}$, as well as that of other gases (not discussed here), was measured with a portable MultiGAS system (Aiuppa et al. 2013 and references therein) along the horizontal and vertical axes of an orthogonal cross-section of the plume. During the measurements the plume was sub-horizontal as the wind was blowing to the East with constant speed. We calculated the average $\mathrm{CO}_{2}$ concentration of $\sim 90$ samples ( $0.5 \mathrm{~Hz}$ sampling rate) every meter on an $8 \mathrm{~m}$ long horizontal axis, and every $0.4 \mathrm{~m}$ on a $2.4 \mathrm{~m}$ high vertical axis. The gas velocity was determined by tracking the transport speeds of individual gas puffs on a video recorder with a Nikon D90 video camera. The measured plume speed of $6.9 \pm 2.2 \mathrm{~m} \mathrm{~s}^{-1}$ leads to a $\mathrm{CO}_{2}$ flux of $3.2 \pm 1.1 \mathrm{t} \mathrm{d}^{-1}$.

\subsection{Soil $\mathrm{CO}_{2}$ flux and temperatures}

Soil $\mathrm{CO}_{2}$ flux $\left(\phi \mathrm{CO}_{2}\right)$ and temperatures (1763 measurements) were measured at Las Máquinas, Las Maquinitas I and II, Anfiteatro, and Termas de Copahue (total investigated area $=1.21 \mathrm{~km}^{2}$; Fig. 1b). The degassing area of Chancho-Co was not investigated due to logistical problems.

Soil $\mathrm{CO}_{2}$ fluxes $\left(\phi \mathrm{CO}_{2}\right)$ were measured using two accumulation chamber devices developed and calibrated at the laboratories of Osservatorio Vesuviano and University of Perugia. The two equipments, operating in a dynamic mode as described in Chiodini et al. (1998), consist of: 1) a metal cylindrical vessel (the chamber, AC), 2) an Infra-Red (IR) spectrophotometer, 3) an analog-digital (AD) converter, and 4) a palmtop computer. The AC has a volume of $\sim 2.8 \mathrm{~L}$ and is equipped with a ring-shaped perforated manifold re-injecting the circulating gas to ensure the mixing of the air in the chamber. The IR spectrometers consist of LICOR Li-800 and LICOR Li-820 detectors equipped with sensors operating in the range $0-20,000 \mathrm{ppm}$ of $\mathrm{CO}_{2}$. The soil gas circulates from the chamber to the IR sensor and vice versa by a pump $\left(\sim 1 \mathrm{~L} \mathrm{~min}^{-1}\right)$. The $\mathrm{CO}_{2}$ concentration inside the $\mathrm{AC}$ is acquired every $250 \mathrm{~ms}$. The signal is converted by the AD and transmitted to a palmtop computer, where a $\mathrm{CO}_{2}$ concentration vs. time diagram is plotted in a real time. The $\phi \mathrm{CO}_{2}$ is computed from the rate of $\mathrm{CO}_{2}$ concentration increase in the chamber $\left(\mathrm{dC}_{\mathrm{CO} 2} / \mathrm{dt}\right)$, according to the following equation:

$\phi \mathrm{CO}_{2}=\mathrm{cf} \times \mathrm{dC}_{\mathrm{CO} 2} / \mathrm{dt}$.

The proportionality factor ( $\mathrm{cf}$ ) between $\mathrm{dC}_{\mathrm{CO} 2} / \mathrm{dt}$ and $\phi \mathrm{CO}_{2}$ was determined before the survey during laboratory tests. The $\phi \mathrm{CO}_{2}$ values, typically from 10 to $10,000 \mathrm{~g} \mathrm{~m}^{-2} \mathrm{~d}^{-1}$, were measured on a "synthetic soil" made of dry sand (10 $\mathrm{cm}$ thick) placed inside a plastic box with an open top. The cf factor was then computed as the slope of the linear best-fit $\phi \mathrm{CO}_{2} \mathrm{vs}$. $\mathrm{dC}_{\mathrm{CO} 2} / \mathrm{dt}$ straight line.

Soil temperature was measured at the depth of $10 \mathrm{~cm}$ by means of a thermocouple equipped with a metallic probe.

The extension of the five surveyed areas, together with the number and the range of the $\mathrm{CO}_{2}$ flux $\left(\phi \mathrm{CO}_{2}\right)$ measurements for each area, is reported in Table 2. The complete set of the $\phi \mathrm{CO}_{2}$ data is available in the supplementary material (SM1).

\subsection{Soil $\mathrm{CO}_{2}$ fluxes and temperature data processing}

The $\phi \mathrm{CO}_{2}$ data were used to compute the total $\mathrm{CO}_{2}$ release from the deep volcanic-hydrothermal source and to map its spatial distribution, as well as that of the soil temperature, by applying the Graphical statistical approach (GSA) and the sequential Gaussian simulation (SGS) methods.

Soil $\mathrm{CO}_{2}$ flux values in hydrothermal areas are characterized by complex statistical distributions, which generally reflect the coexistence of different $\mathrm{CO}_{2}$ sources such as biogenic and endogenous (Cardellini et al., 2003). In a logarithmic probability plot, where a straight line describes one log-normal population, these complex distributions result on a curve with $n$ inflection points, which describes the overlapping of $n+1$ log-normal populations.

Table 1

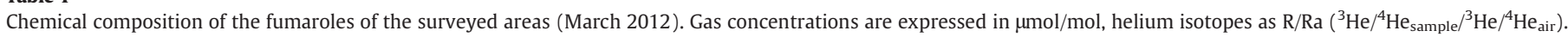

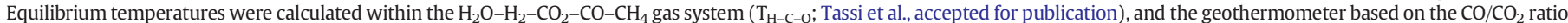
( $\mathrm{T}_{\mathrm{CO}-\mathrm{CO} 2}$; Chiodini et al., 2015).

\begin{tabular}{|c|c|c|c|c|c|c|c|c|c|c|c|c|}
\hline Name & $\begin{array}{l}\mathrm{T} \\
{ }^{\circ} \mathrm{C}\end{array}$ & $\mathrm{H}_{2} \mathrm{O}$ & $\mathrm{CO}_{2}$ & $\mathrm{H}_{2} \mathrm{~S}$ & $\mathrm{~N}_{2}$ & $\mathrm{CH}_{4}$ & $\mathrm{H}_{2}$ & $\mathrm{He}$ & $\mathrm{CO}$ & ${ }^{3} \mathrm{He} /{ }^{4} \mathrm{He}$ & $\begin{array}{l}\mathrm{T}_{\mathrm{H}-\mathrm{C}-\mathrm{O}} \\
{ }^{\circ} \mathrm{C}\end{array}$ & $\begin{array}{l}\mathrm{T}_{\mathrm{CO}-\mathrm{CO} 2} \\
{ }^{\circ} \mathrm{C}\end{array}$ \\
\hline Las Máquinas & 96 & 973,000 & 25,200 & 189 & 511 & 540 & 395 & 0.32 & 0.057 & 7.04 & 203 & 206 \\
\hline Las Maquinitas & 160 & 976,000 & 23,100 & 214 & 521 & 290 & 312 & 0.32 & 0.049 & 6.97 & 210 & 204 \\
\hline Termas de Copahue & 95 & 975,000 & 24,100 & 212 & 449 & 286 & 319 & 0.30 & 0.052 & 7.01 & 210 & 204 \\
\hline Anfiteatro & 92 & 989,000 & 9470 & 213 & 4045 & 641 & 184 & 0.24 & 0.068 & 4.93 & 258 & 244 \\
\hline
\end{tabular}


Table 2

Main parameters of the five surveyed areas.

\begin{tabular}{lclc}
\hline Name & $\begin{array}{l}\text { Extension } \\
\left(\mathrm{m}^{2}\right)\end{array}$ & No. of points & $\begin{array}{l}\text { Mean }(\min -\max ) \phi \mathrm{CO}_{2} \\
\left(\mathrm{~g} \mathrm{~m}^{-2} \mathrm{~d}^{-1}\right)\end{array}$ \\
\hline Las Máquinas & 320,823 & 495 & $145(<0.05-7,270)$ \\
Las Maquinitas I & 45,842 & 141 & $78(<0.05-2,200)$ \\
Las Maquinitas II & 32,802 & 103 & $272(<0.05-14,330)$ \\
Anfiteatro & 26,089 & 346 & $105(<0.05-16,560)$ \\
Termas de Copahue & 575,748 & 678 & $195(<0.05-9,380)$ \\
Total & $1,212,585$ & 1763 & $158(<0.05-16,560)$ \\
\hline
\end{tabular}

The GSA method (Chiodini et al., 1998) was used to both partitioning these distributions into the individual log-normal populations and estimating their proportion $\left(f_{i}\right)$, mean value and standard deviation. The partition was performed according to the graphical procedure proposed by Sinclair (1974). Since the computed statistical parameters of the populations (i.e. mean and standard deviation) refer to the logarithm of values, the mean value of $\phi \mathrm{CO}_{2}\left(M_{i}\right)$ and the central $90 \%$ confidence interval of the mean were estimated by means of a Monte Carlo procedure. The estimated mean flux values were used to compute the $\mathrm{CO}_{2}$ released from the investigated areas and associated with each population by multiplying $M_{i}$ by the respective covered surface $\left(S_{i}\right)$, the latter being assumed as a fraction of the total surveyed area $(S)$, which corresponds to the relative proportion of the population (i.e. $S_{i}=f_{i} \times S$ ). The total $\mathrm{CO}_{2}$ release from the entire area can then be obtained by summing up the contribution of each population (i.e. $\Sigma f_{i} \times M_{i} \times S$ ). Similarly, the central $90 \%$ confidence interval of the mean value was used to calculate the uncertainty of the total $\mathrm{CO}_{2}$ output estimation of each population.

Although the GSA approach is a useful tool for the interpretation of the diffuse degassing process, the results obtained by this method can be affected by some arbitrary choices, as follows: i) the polymodal log-normal distribution of $\mathrm{CO}_{2}$ flux values is a convenient model for subsequent partitioning. Nevertheless, the statistical distribution of the $\mathrm{CO}_{2}$ flux can be more complex than that of a simple log-normal distribution, ii) the partitioning procedure does not imply a unique solution, iii) the spatial distribution of the measured values is not considered by this statistical approach, and iv) the interpretations of the $\mathrm{CO}_{2}$ flux distribution at the tails, especially for high flux values, can highly be affected by a low number of measured values. As a consequence of the latter "choice", the estimate of the total $\mathrm{CO}_{2}$ output can be subjected to remarkable differences.

An alternative and more reliable estimation of the total $\mathrm{CO}_{2}$ output can be obtained from the $\mathrm{CO}_{2}$ flux mapping by the Sequential Gaussian Simulation (SGS) algorithm provided by the sgsim code (Deutsch and Journel, 1998). According to Cardellini et al. (2003) and Lewicki et al. (2005), SGS yields a realistic representation of the spatial distribution of the $\mathrm{CO}_{2}$ fluxes reproducing the histogram and variogram of the original data.

The SGS method produces numerous equiprobable and alternative simulations of the spatial distribution of the attribute, i.e. $\mathrm{CO}_{2}$ flux and temperature in this work. Since the SGS procedure requires a multiGaussian distribution, original data were transformed into normal distribution by a normal score transform (Deutsch and Journel, 1998; Cardellini et al., 2003). Experimental variograms of the normal scores were computed and modeled for each data set. The models were used in the SGS procedure to create 200 simulations of the normal scores. The simulated normal scores were then back-transformed into values expressed in original data units, applying the inverse of the normal score transform. The average of the values simulated at each cell of the grid in the 200 simulations was used to draw the maps of soil $\mathrm{CO}_{2}$ flux and soil temperature. For each simulation the total $\mathrm{CO}_{2}$ release was computed by summing up the products of the simulated value of each grid cell by the cell surface. The mean and the standard deviation of the 200 values of total $\mathrm{CO}_{2}$ output were assumed to be the characteristic values of the $\mathrm{CO}_{2}$ release and of its uncertainty, respectively, for each surveyed area.

\section{Results and discussions}

\section{1. $\mathrm{CO}_{2}$ soil degassing}

The investigated areas were characterized by a wide range of $\mathrm{CO}_{2}$ flux values, which varied from $<0.05 \mathrm{~g} \mathrm{~m}^{-2} \mathrm{~d}^{-1}$ to $>16,560 \mathrm{~g} \mathrm{~m}^{-2} \mathrm{~d}^{-1}$ (Table. 2). Each data set is reported in the logarithmic probability plots of Fig. 2. These diagrams show the results of the GSA analysis, which includes i) the partitioned log-normal populations (blue straight lines), ii) their proportion, mean and standard deviation, and iii) the theoretical statistical distribution resulting from the combinations of the individual populations (red dashed curves).

The proportion, mean and standard deviation and the total $\mathrm{CO}_{2}$ output calculated for each population are reported in Table 3.

On the basis of the mean flux values characterizing the different populations, an interpretation of the main $\mathrm{CO}_{2}$ source is reported in Table 3. "Background" refers to $\mathrm{CO}_{2}$ fluxes related to soil respiration, whereas the term "endogenous" is related to those fluxes fed by volcanichydrothermal degassing. The latter includes those populations characterized by high mean $\phi \mathrm{CO}_{2}$ values, typically in the order of $10^{3} \mathrm{~g} \mathrm{~m}^{-2} \mathrm{~d}^{-1}$, i.e. much higher than those produced by biogenic sources in the soil, which typically are 2-3 order of magnitude lower (e.g., Raich and Schlesinger, 1992; Raich and Tufekcioglu, 2000; Cardellini et al., 2003). At Las Máquinas, Anfiteatro and Termas de Copahue, the distribution of the $\mathrm{CO}_{2}$ flux values in the probability plots indicates the presence of more than one "background" population (Table 3). The occurrence of different background populations possibly reflects the presence of different soils and vegetation in the surveyed areas. The background populations with the lowest mean values of $\phi \mathrm{CO}_{2}$ (normally $<1 \mathrm{~g} \mathrm{~m}^{-2} \mathrm{~d}^{-1}$ ) correspond to fluxes from bare altered soils. Such low values could nevertheless be referred to an endogenous source, although their origin cannot properly be assessed since no isotopic carbon values of the $\mathrm{CO}_{2}$ efflux (Chiodini et al., 2008) are available. However, it is to be pointed out that contributions by low flux populations to the total $\mathrm{CO}_{2}$ budget are negligible. The relatively high $\phi \mathrm{CO}_{2}$ values, which characterize the background populations "B" at Las Máquinas $\left(24 \mathrm{~g} \mathrm{~m}^{-2} \mathrm{~d}^{-1}\right), \mathrm{C}$ at Anfiteatro $\left(26 \mathrm{~g} \mathrm{~m}^{-2} \mathrm{~d}^{-1}\right)$, and $\mathrm{B}$ at Termas de Copahue $\left(22 \mathrm{~g} \mathrm{~m}^{-2} \mathrm{~d}^{-1}\right)$, are mainly representative of the presence in the surveyed areas of wet soils and peat (Table 3).

The estimated total $\mathrm{CO}_{2}$ outputs using the GSA approach, i.e. the sum of all contributions from the different populations, range from $4.4 \mathrm{t} \mathrm{d}^{-1}$ (Las Maquinitas I) to $119 \mathrm{t} \mathrm{d}^{-1}$ (Termas de Copahue). The central $90 \%$ confidence interval of the mean value is generally large and, especially at Anfiteatro and Las Maquinitas II, it varies one order of magnitude (11-110 t d $\mathrm{d}^{-1}$ and 4-44 $\mathrm{t} \mathrm{d}^{-1}$, respectively). These large uncertainties mainly depend on the relatively low number of samples available for the definition of the high-flux populations, which mostly contribute to the total $\mathrm{CO}_{2}$ output. On the contrary, the computations of the background populations are affected by a lower uncertainty because they are less variable and are defined by numerous samples (Fig. 2, Table 3). Assuming that $\mathrm{CO}_{2}$ of the background populations is totally derived from shallow biogenic sources (soil respiration, e.g. Raich and Schlesinger, 1992), the total background $\mathrm{CO}_{2}$ output is of $5.9 \mathrm{t} \mathrm{d}^{-1}$ at Las Máquinas, nil at Las Maquinitas I, $0.09 \mathrm{t} \mathrm{d}^{-1}$ at Las Maquinitas II, $3.3 \mathrm{t} \mathrm{d}^{-1}$ at Anfiteatro and $9.2 \mathrm{t} \mathrm{d}^{-1}$ at Termas de Copahue.

In order to map the $\mathrm{CO}_{2}$ fluxes and to compute the total gas release using the SGS approach, experimental variograms of the normal scores of the data were computed and modeled for each data set (Table 4). The models were used in the SGS procedure to create 200 simulations of the $\mathrm{CO}_{2}$ flux according to the computation grids described in Table 4 . The obtained $\mathrm{CO}_{2}$ flux maps are reported in Fig. 3 .

All the surveyed areas are characterized by a well-defined diffuse degassing structure (DDS), except at Anfiteatro where the $\mathrm{CO}_{2}$ fluxes are less spatially organized.

The total SGS-computed $\mathrm{CO}_{2}$ release ranged from $5 \mathrm{t} \mathrm{d}^{-1}$ (Las Maquinitas I) to $100 \mathrm{t} \mathrm{d}^{-1}$ (Termas de Copahue) with a relatively low 

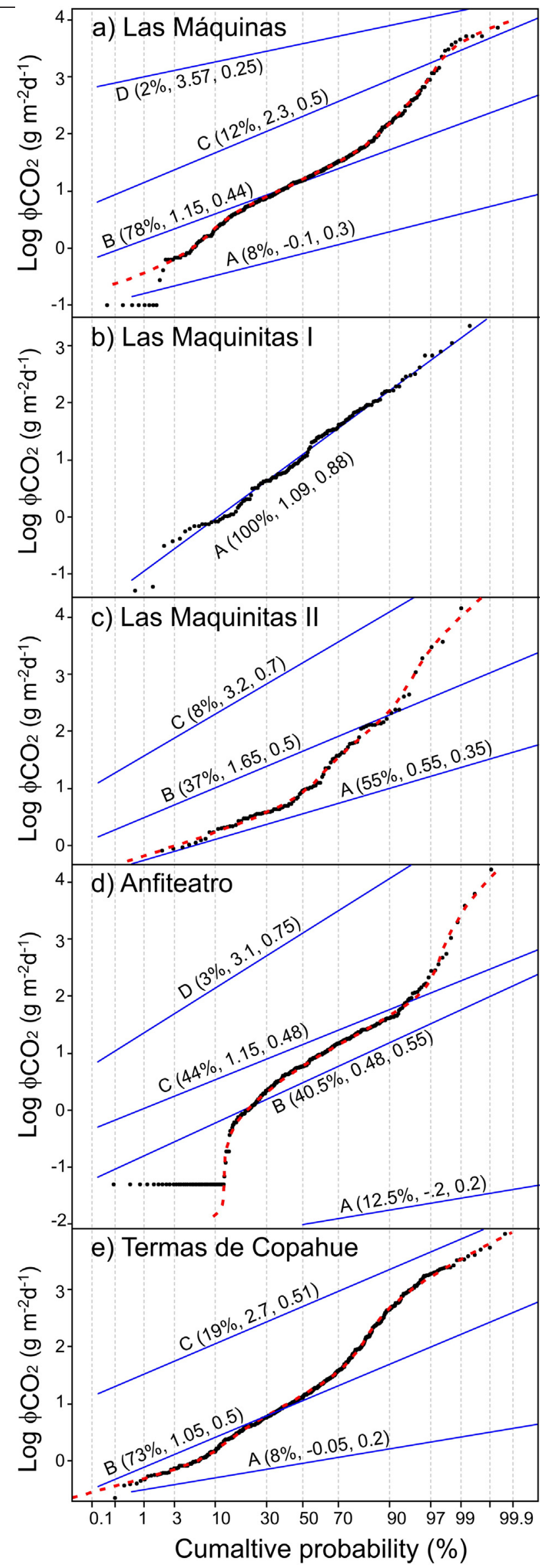

uncertainty ( $\leq 10 \%$; Table 4$)$. These values can be considered comparable with those obtained by the GSA approach, except for Las Maquinitas II and Anfiteatro, where the SGS estimates are about 50\% less than those obtained by GSA. These differences are likely related to an overestimation computed by GSA because a relatively low number of $\mathrm{CO}_{2}$ flux measurements are available for the definition of the high flux populations. For this reason, the total $\mathrm{CO}_{2}$ release obtained by the SGS approach was preferred for further computations.

The amount of released endogenous $\mathrm{CO}_{2}\left(\mathrm{Q}_{\mathrm{CO} 2}\right)$ was computed for each area by subtracting the specific background contribution estimated by GSA to the total $\mathrm{CO}_{2}$ release estimated by SGS. The computed $\mathrm{Q}_{\mathrm{CO} 2}$ varies from $5 \mathrm{t} \mathrm{d}^{-1}$ (Las Maquinitas I) to $90.8 \mathrm{t} \mathrm{d}^{-1}$ (Termas de Copahue) (Table 4).

\subsection{Soil temperature distribution}

The soil temperature maps obtained by applying the SGS algorithm are reported in Fig. 4 and refer to the temperature at $10 \mathrm{~cm}$ depth, concurrently measured with each $\phi \mathrm{CO}_{2}$ measurement.

Setting aside Anfiteatro, the soil temperature spatial distribution (Fig. 4) in the investigated areas closely mimics that of $\phi \mathrm{CO}_{2}$ (Fig. 3). A correlation between soil temperature and $\phi \mathrm{CO}_{2}$ is not surprising because the presence of fumarolic emission favors a massive steam condensation at shallow depth, heating the soil by the latent heat of condensation and causing a flux of incondensable gases (i.e. mostly $\mathrm{CO}_{2}$ ) toward the surface (Chiodini et al., 2001; Chiodini et al. 2005). Accordingly, in areas of fumarolic discharges, hot soils and anomalous diffuse soil degassing of incondensable gases, $\mathrm{CO}_{2}$ flux can be used as a tracer of the whole process allowing an estimation of the total amount of steam and thermal energy involved in the process.

\subsection{The hydrothermal system feeding soil diffuse degassing and structural control on DDS}

The main fumarolic emissions located in the five surveyed zones (Figs. 1-4) were sampled and analyzed in 2012. The concentration of main and relevant gas species, $\mathrm{C}$ and He isotopes and the temperature estimations calculated by gas geothermometry are reported in Table 1. $\mathrm{H}_{2} \mathrm{O}$ is by far the main component, being $>97 \%$ by volume in all the fumaroles. The second component is $\mathrm{CO}_{2}$, followed by minor amount of $\mathrm{N}_{2}, \mathrm{H}_{2}, \mathrm{CH}_{4}$ and $\mathrm{H}_{2} \mathrm{~S}$. CO and He concentrations are $<1 \mathrm{ppm}$ by volume. The absence of the strong acidic gases (i.e. $\mathrm{SO}_{2}, \mathrm{HCl}$ and $\mathrm{HF}$ ), which are typical of high temperature fumaroles from active volcanic systems, and the relatively high $\mathrm{CH}_{4}$ contents suggest that these gases are intimately related to a hydrothermal system. According to Agusto et al. (2013), the fumarolic fluids are originated by boiling of a hydrothermal reservoir, mainly fed by meteoric water. However, the high ${ }^{3} \mathrm{He} /{ }^{4} \mathrm{He}$ ratios (R/Ra up to 7.04), the $\delta^{13} \mathrm{C}_{-}-\mathrm{CO}_{2}$ values of $-7 \%$ and the $\mathrm{N}_{2} / \mathrm{Ar}$ ratios much higher than those of ASW (Air Saturated Water), suggest that $\mathrm{He}, \mathrm{N}_{2}$ and $\mathrm{CO}_{2}$ are mainly supplied to the hydrothermal system by a magmatic source (Agusto et al., 2013; Tassi et al., accepted for publication). Three deep wells, drilled in the eighties in the frame of a geothermal project (COP-1, COP-2 and COP-3 in Fig. 5; Dellapé and Pando, 1975; Jurío, 1977; Panarello et al., 1988; JICA-EPEN, 1992; Sierra et al. 1992; Mas et al., 2000), provided direct information on the hydrothermal system feeding the CCVC diffuse degassing structures. All the 3 wells, which are located $1-2 \mathrm{~km} \mathrm{~S}$ or $\mathrm{W}$ of the studied hydrothermal sites (Fig. 5), reached a deep reservoir of high temperatures (240$260{ }^{\circ} \mathrm{C}$ ) and a shallower vapor dominated zone at depths of 800 $1000 \mathrm{~m}$ for which temperatures from 200 to $215^{\circ} \mathrm{C}$ were measured and/or estimated with geochemical indicators (Sierra et al., 1990; Panarello, 2002).

Fig. 2. Probability plots of $\log \phi \mathrm{CO}_{2}$ for the different hydrothermal sites and partition of the distributions in log-normal populations (blue lines). (For interpretation of the references to color in this figure legend, the reader is referred to the web version of this article.) 
Table 3

Estimated parameters and partitioned populations in the 5 surveyed areas.

\begin{tabular}{|c|c|c|c|c|}
\hline Name & Population & $\begin{array}{l}\text { Proportion } \\
(\%)\end{array}$ & $\begin{array}{l}\text { Average } \phi \mathrm{CO}_{2} \text { and } 90 \% \text { confidence } \\
\text { interval }\left(\mathrm{g} \mathrm{m}^{-2} \mathrm{~d}^{-1}\right)\end{array}$ & $\begin{array}{l}\text { Total diffuse } \mathrm{CO}_{2} \text { output and } 90 \% \\
\text { confidence interval }\left(\mathrm{t} \mathrm{d}^{-1}\right)\end{array}$ \\
\hline \multirow[t]{5}{*}{ Las Máquinas } & A (background) & 8 & $1.01(0.82-1.23)$ & $0.03(0.02-0.03)$ \\
\hline & B (background) & 78 & $24(22-27)$ & $5.9(5.3-6.6)$ \\
\hline & C (endogenous) & 12 & $388(276-538)$ & $15(11-21)$ \\
\hline & D (endogenous) & 2 & $4379(3058-6038)$ & $28(20-39)$ \\
\hline & Total & 100 & & $49(36-66)$ \\
\hline Las Maquinitas I & A (endogenous) & 100 & $95(49-181)$ & $4.4(2.2-8.3)$ \\
\hline \multirow[t]{4}{*}{ La Maquinitas II } & A (background) & 55 & $4.9(4-6)$ & $0.09(0.07-.11)$ \\
\hline & B (endogenous) & 37 & $86(56-128)$ & $1(0.7-1.6)$ \\
\hline & C (endogenous) & 8 & $5815(1298-1,5995)$ & $15.3(3.4-42)$ \\
\hline & Total & 100 & & $16(4-44)$ \\
\hline \multirow[t]{5}{*}{ Anfiteatro } & A (background) & 12.5 & $<0.1$ & nd \\
\hline & B (background) & 40.5 & $6.7(5.2-8.7)$ & $0.64(0.49-0.83)$ \\
\hline & C (background) & 44 & $26(21-32)$ & $2.7(2.2-3.3)$ \\
\hline & D (endogenous) & 3 & $5634(1213-15,022)$ & $40(9-106)$ \\
\hline & Total & 100 & & $43(11-110)$ \\
\hline \multirow[t]{4}{*}{ Termas de Copahue } & A (background) & 8 & $0.99(0.89-1.10)$ & $0.05(0.04-0.05)$ \\
\hline & B (background) & 73 & $22(19-25)$ & $9.2(8.1-10.4)$ \\
\hline & C (endogenous) & 19 & $1000(784-1270)$ & $109(86-139)$ \\
\hline & Total & 100 & & $119(94-174)$ \\
\hline
\end{tabular}

Geothermometric calculations in the $\mathrm{H}_{2} \mathrm{O}-\mathrm{CO}_{2}-\mathrm{CH}_{4}-\mathrm{CO}-\mathrm{H}_{2}$ gas system (Tassi et al., accepted for publication) indicated that the fumarolic fluids discharged at Piedra Copahue, Las Máquinas and Las Maquinitas equilibrate in a single vapor phase, as actually observed by the geothermal wells, at a temperature of $203-210{ }^{\circ} \mathrm{C}\left(\mathrm{T}_{\mathrm{H}-\mathrm{C}-\mathrm{O}}\right.$ in Table 1$)$. Other computations, based on the $\mathrm{CO} / \mathrm{CO}_{2}$ ratios by applying the same method described in Chiodini et al. (2015), produced similar temperatures ( $\mathrm{T}_{\mathrm{CO}-}$ $\mathrm{CO} 2 \sim 204-206{ }^{\circ} \mathrm{C}$; Table 1 ). These estimations are in good agreement with the temperatures measured in the geothermal wells, suggesting the occurrence of a large, probably unique, vapor zone reached by the wells and feeding the hydrothermal manifestations of Termas de Copahue, Las Máquinas and Las Maquinitas ("hot area with evidences of a single phase vapor zone at depth" in Fig. 5). This would explain the remarkable chemical and isotopic homogeneity of the fumaroles from the 3 different sites (Table 1), which are distant a few kilometers from each other (Fig. 5). The three fumaroles show, for example, a similar $\mathrm{H}_{2} \mathrm{O} / \mathrm{CO}_{2}$ molar ratio of $\sim 40$ and ${ }^{3} \mathrm{He} /{ }^{4} \mathrm{He}$ of $\sim 7 \mathrm{R} / \mathrm{Ra}$.

In order to better understand the role of this vapor zone in the hydrothermal circulation, the structural setting of the zone needs to be considered. The caldera is locally characterized by three fault systems, which are NE-SW, WNW-ESE and NW-SE oriented (Melnick et al., 2006; Rojas Vera et al., 2010; Latinoconsult, 1981; JICA-EPEN, 1992). These three fault systems are arranged in such a way that they constitute the borders of a triangle-shaped horst structure which, according to gravity and electrical resistivity surveys, represents a high conductivity zone of hot fluids circulation (JICA-EPEN, 1992). The geometries of the DDS's, as defined by the $\phi \mathrm{CO}_{2}$ distribution, are roughly consistent with these three directions (Fig. 5). In particular at Termas de Copahue, Las Maquinitas I and II the high $\mathrm{CO}_{2}$ fluxes seem to be mainly distributed along the NE-SW-aligned structures, which correspond to either known faults or faults inferred by this investigation on the basis of diffuse degassing processes active in this area. At Las Máquinas, the DDS develops along both NE-SW and WNW-ESE structural trends. The general correspondence between the structural trends and the DDS geometries suggests that the emission of the hydrothermal fluids is favored by the fault systems, which cut through the vapor zone, causing the transfer of the deep fluids toward the surface. In Fig. 5, the extension of such vapor zone was roughly delimited: the studied DDS would be located in the northern and eastern limits of this "hot area" with the exception of Anfiteatro which, according to this hypothesis, would be positioned externally with respect to the "hot area". This is supported by the chemical and isotopic composition of the fumarolic fluids discharged at Anfiteatro, as they significantly differ from the other areas. The Anfiteatro fumaroles are indeed richer in water $\left(\mathrm{H}_{2} \mathrm{O} / \mathrm{CO}_{2}\right.$ molar ratio of $\sim 100$ ) and the ${ }^{3} \mathrm{He} /{ }^{4} \mathrm{He}$ ratio is significantly lower (R/ $\mathrm{Ra} \sim 4.9$ ) than those measured at Las Máquinas, Las Maquinitas and Piedra Copahue.

\subsection{Estimation of the thermal energy release}

At the Copahue hydrothermal sites, the thermal energy release was estimated by using an approach similar to that described in Chiodini et al. $(2001 ; 2005)$. The computation was based on (i) the estimation of the pristine $\mathrm{H}_{2} \mathrm{O} / \mathrm{CO}_{2}$ ratio ( $\mathrm{R}_{\mathrm{H} 2 \mathrm{O}-\mathrm{CO} 2}$ by weight) of the fluid feeding the soil diffuse gas emission before steam condensation and (ii) the computation of the total steam involved in the process $Q_{\text {steam }}$ by multiplying $\mathrm{Q}_{\mathrm{CO} 2 \mathrm{~d}}$ by $\mathrm{R}_{\mathrm{H} 2 \mathrm{O}-\mathrm{CO} 2}$. In the case of Las Maquinitas, the measured fumarolic $\mathrm{CO}_{2}$ flux $\left(3.2 \mathrm{t} \mathrm{d}^{-1}\right.$ ) was added to the diffuse $\mathrm{CO}_{2}$ output. In each hydrothermal site, $Q_{\text {steam }}$ was computed with the reasonable assumption that $\mathrm{R}_{\mathrm{H} 2 \mathrm{O}-\mathrm{CO} 2}$ is equal to the $\mathrm{H}_{2} \mathrm{O} / \mathrm{CO}_{2}$ ratio measured in the fumaroles of the correspondent degassing structure (Table 5). The total amount of steam from each area $\left(Q_{\text {steam }}\right)$ varies from $285 \mathrm{t} \mathrm{d}^{-1}$ at La Maquinitas to $1506 \mathrm{t} \mathrm{d}^{-1}$ at Termas de Copahue (Table 5). The

Table 4

Relevant parameters of SGS application and estimation of the total $\mathrm{CO}_{2}$ output from Copahue hydrothermal sites.

\begin{tabular}{|c|c|c|c|c|}
\hline Site name & $\begin{array}{l}\text { Variogram model, nugget, } \\
\text { range }(\mathrm{m})\end{array}$ & $\begin{array}{l}\text { Grid parameters: } n \text {. } \\
\text { cells, lag }(\mathrm{m})\end{array}$ & $\begin{array}{l}\text { Total } \mathrm{CO}_{2} \text { release } \pm \text { standard } \\
\text { deviation }\left(\mathrm{t} \mathrm{d}^{-1}\right)\end{array}$ & $\begin{array}{l}\text { Endogenous } \mathrm{CO}_{2} \text { release, } \\
\mathrm{Q}_{\mathrm{CO} 2}\left(\mathrm{t} \mathrm{d}^{-1}\right)\end{array}$ \\
\hline Las Máquinas & Spherical, 0.47, 145 & $35,647,3$ & $42.7 \pm 4.33$ & 36.8 \\
\hline Las Maquinitas I & Spherical, 0.51, 50 & $45,842,1$ & $5.01 \pm 0.81$ & $5.0(1)$ \\
\hline Las Maquinitas II & Spherical, 0.46, 66 & $32,802,1$ & $8.30 \pm 1.56$ & 8.3 \\
\hline Anfiteatro & Spherical, 0.71, 80 & $29,748,3$ & $24.0 \pm 2.45$ & 21.7 \\
\hline Termas de Copahue & Spherical, 0.59, 194 & $63,972,3$ & $100 \pm 5.42$ & 90.8 \\
\hline Total & - & - & 180 & 162.6 \\
\hline
\end{tabular}

(1) At Las Maquinitas I, an additional $\mathrm{CO}_{2}$ flux of $\sim 3.2 \mathrm{t} \mathrm{d}^{-1}$ was measured from the main fumarolic vent. 

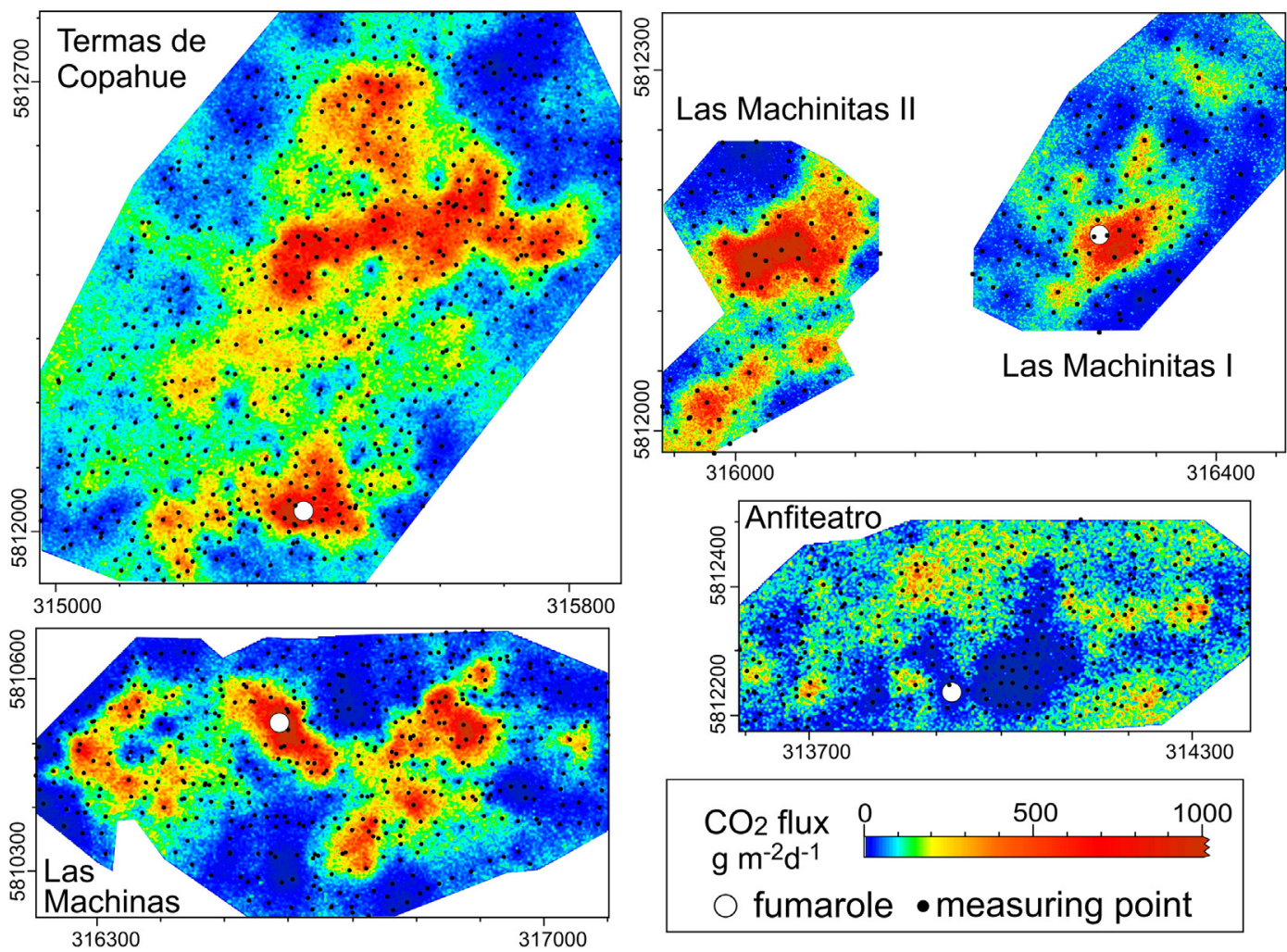

Fig. 3. Maps of the $\mathrm{CO}_{2}$ flux for the different hydrothermal sites (map coordinates are expressed in m, UTM-WGS84 19S).
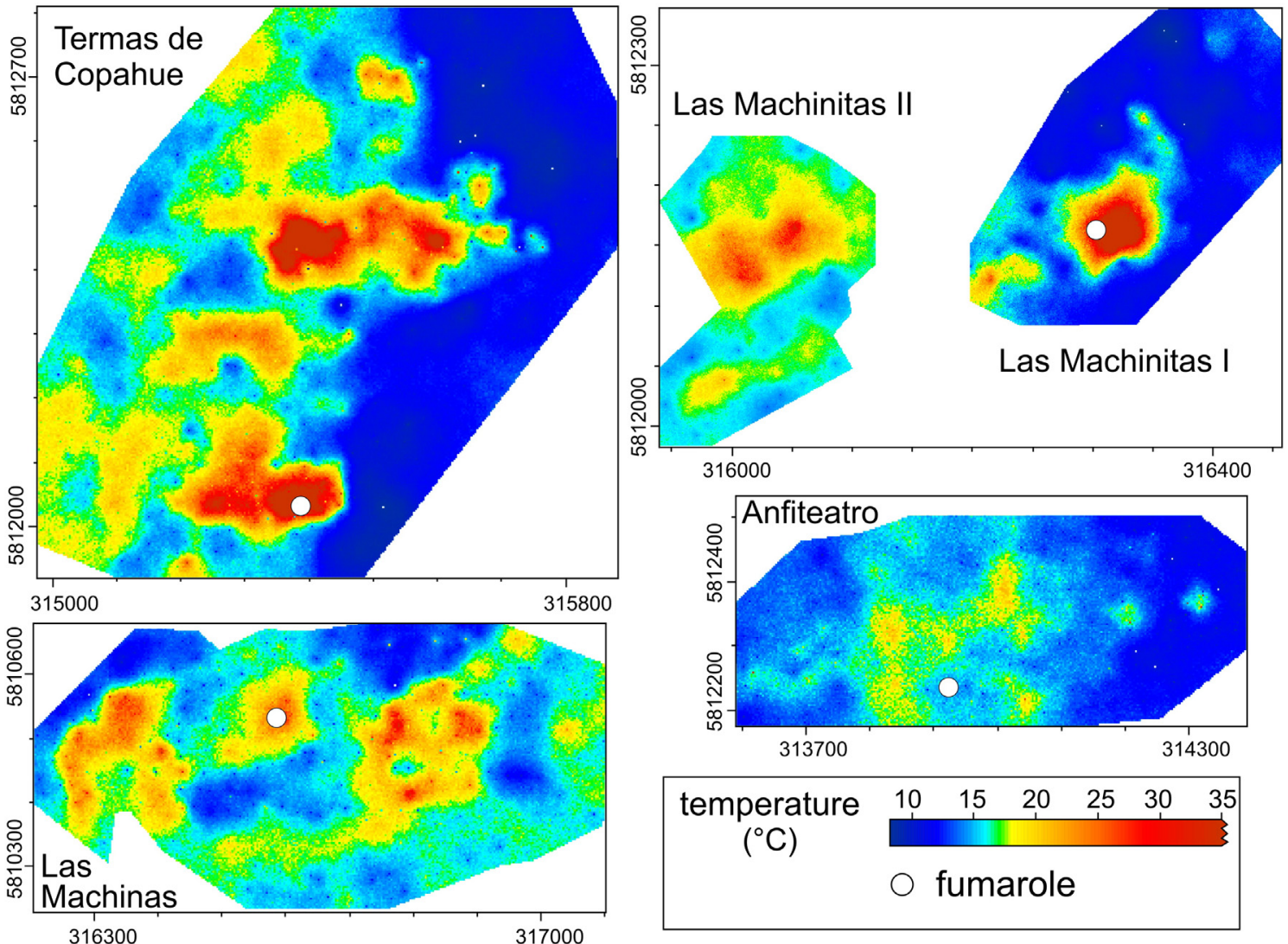

Fig. 4. Maps of soil temperature for the different hydrothermal sites (map coordinates are expressed, in m UTM-WGS84 19S). 


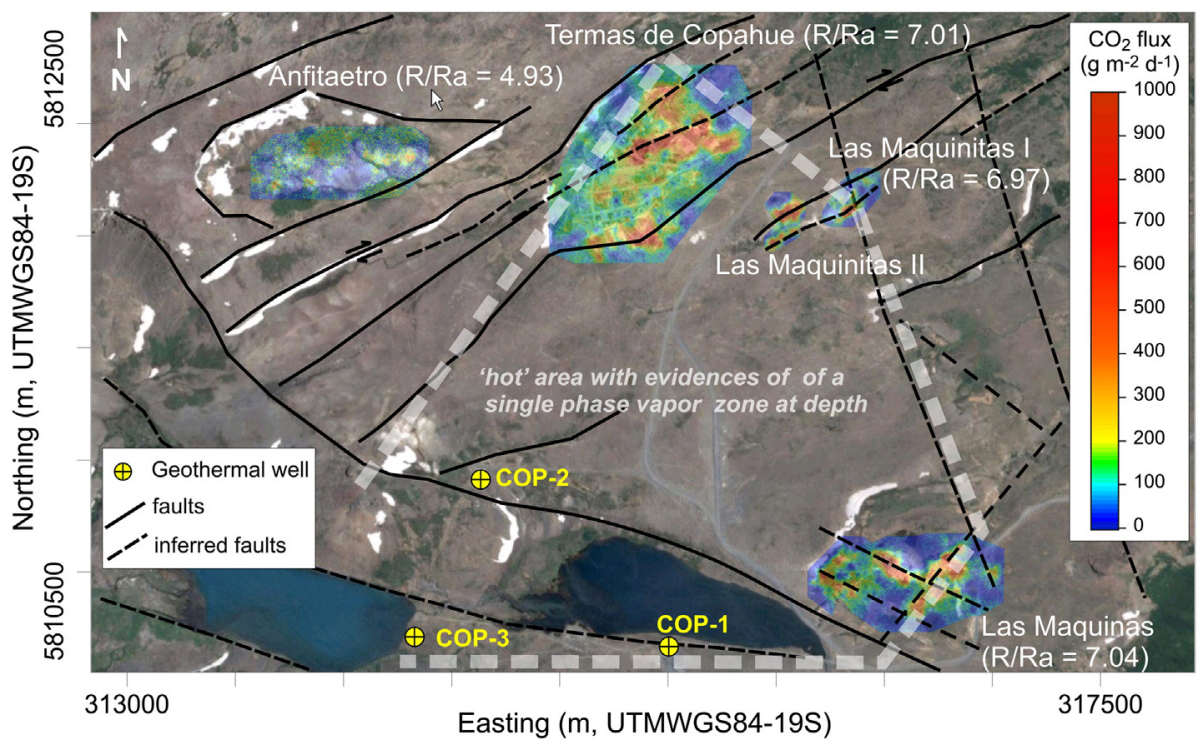

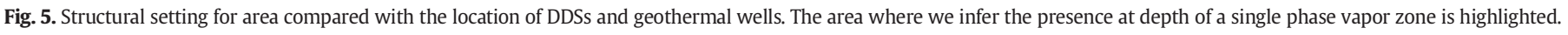

total thermal release $\mathrm{QH}_{\text {tot }}$ (Table 5) was calculated by adding three contributions:

(1) $\mathrm{QH}_{\mathrm{res}}$ represents the heat released by the $\mathrm{H}_{2} \mathrm{O}-\mathrm{CO}_{2}$ gas mixture moving from the reservoir conditions to the condensation zone. The reservoir temperatures were considered equal to $210{ }^{\circ} \mathrm{C}$, whilst the reservoir pressure was assumed that of the saturated vapor at which $\mathrm{P}_{\mathrm{CO} 2}$, computed by multiplying $\mathrm{P}_{\mathrm{H} 2 \mathrm{O}}$ by the measured fumarolic $\mathrm{CO}_{2} / \mathrm{H}_{2} \mathrm{O}$ molar ratio, was added. $\mathrm{QH}_{\mathrm{res}}$ was calculated by multiplying $\mathrm{Q}_{\text {steam }}$ by the enthalpy difference between the vapor at reservoir conditions and at condensation conditions ( $0.096 \mathrm{Mpa}$ and $\left.98{ }^{\circ} \mathrm{C}\right)$. The computation was performed using MUFITS software, which allows prediction of $\mathrm{CO}_{2}-\mathrm{H}_{2} \mathrm{O}$ mixture properties in a wide range of pressures and temperatures (Afanasyev, 2013). $\mathrm{QH}_{\text {res }}$ ranges from $0.5 \mathrm{MW}$ to 3.6 MW, thus it is the minor term of the energetic balance of the diffuse degassing structures (Table 5);

(2) $\mathrm{QH}_{\text {cond }}$ corresponds to the heat released during steam condensation at subsurface conditions. The $\mathrm{QH}_{\text {cond }}$ values, which were computed by multiplying $\mathrm{Q}_{\text {steam }}$ by the latent heat of condensation at $98^{\circ} \mathrm{C}\left(2262 \mathrm{~J} \mathrm{~g}^{-1}\right)$, range from 7.5 MW at Las Maquinitas I and II areas to 39.4 MW at Termas de Copahue (Table 5). $\mathrm{QH}_{\text {cond }}$ is the main term of the energy budget;

(3) $\mathrm{QH}_{\text {cooling }}$ is the heat released as the condensates cool down to ambient temperature. It was estimated by multiplying $Q_{\text {steam }}$ by the enthalpy difference between the liquid at $98{ }^{\circ} \mathrm{C}$ (enthalpy $=411 \mathrm{~J} \mathrm{~g}^{-1}$ ) and at $10{ }^{\circ} \mathrm{C}\left(\right.$ enthalpy $\left.=42 \mathrm{~J} \mathrm{~g}^{-1}\right)$.

Table 5

Heat flux estimation.

\begin{tabular}{|c|c|c|c|c|c|c|}
\hline Hydrothermal site & $\mathrm{R}_{\mathrm{H} 2 \mathrm{O}-\mathrm{CO} 2}$ & $\begin{array}{l}\mathrm{Q}_{\text {steam }} \\
\left(\mathrm{t} \mathrm{d}^{-1}\right)\end{array}$ & $\begin{array}{l}\mathrm{QH}_{\mathrm{res}} \\
(\mathrm{MW})\end{array}$ & $\begin{array}{l}\mathrm{QH}_{\text {cond }} \\
\text { (MW) }\end{array}$ & $\begin{array}{l}\mathrm{QH}_{\text {cooling }} \\
(\mathrm{MW})\end{array}$ & $\begin{array}{l}\mathrm{QH}_{\text {tot }} \\
(\mathrm{MW})\end{array}$ \\
\hline Las Máquinas & 15.8 & 581 & 1.2 & 15.2 & 2.5 & 18.9 \\
\hline Las Maquinitas I, II ${ }^{\mathrm{a}}$ & 17.3 & 285 & 0.5 & 7.5 & 1.2 & 9.1 \\
\hline Termas de Copahue & 16.6 & 1506 & 3.2 & 39.4 & 6.4 & 49.1 \\
\hline Anfiteatro & 42.7 & 927 & 2.2 & 24.3 & 4.0 & 30.4 \\
\hline Total & - & 3244 & & & & 107.5 \\
\hline
\end{tabular}

a At Las Maquinitas $\mathrm{Q}_{\text {steam }}$ includes the contribution of the main fumarolic vent which was computed in $55 \mathrm{t} \mathrm{d}^{-1}$ by multiplying the measured $\mathrm{CO}_{2}$ flux $\left(3.2 \mathrm{t} \mathrm{d}^{-1}\right)$ by $\mathrm{R}_{\mathrm{H} 2 \mathrm{O}-\mathrm{CO} 2}$

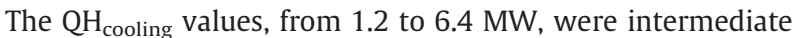
between those of $\mathrm{QH}_{\text {res }}$ and $\mathrm{QH}_{\text {cond }}$ (Table 5).

The total thermal energy release from the five-surveyed zones is 107.5 MW. The highest thermal energy release (49.1 MW) was estimated at Termas de Copahue, where the computed $\mathrm{Q}_{\text {steam }}$ was $1506 \mathrm{t} / \mathrm{d}$. Here, the production of large amount of condensates is shown by the mass balance calculated for the small creek (Rio Frio, Fig. 1) that enters the village with a flow rate of $560 \mathrm{t} \mathrm{d}^{-1}\left(\mathrm{pH}=6.06, \mathrm{~T}=16.2^{\circ} \mathrm{C}\right)$, collects the great majority of the condensation waters and flows out at the rate of $1460 \mathrm{t} \mathrm{d}^{-1}\left(\mathrm{pH}=3.4, \mathrm{~T}=22.5^{\circ} \mathrm{C}\right)$. The measured flow rate increment, which is about $60 \%$ of the estimated condensate production in the area, appears to be realistically supporting the reliability of our estimation. It is indeed reasonable that part of the condensates is feeding the local aquifer (groundwater circulation).

\section{Conclusions}

The north-western sector of the Caviahue caldera is characterized by fumarolic emissions associated with zones of anomalously high soil $\mathrm{CO}_{2}$ diffuse degassing and soil temperature. Five of these sites were investigated and a total discharge of deeply-originated $\mathrm{CO}_{2}$ of $\sim 165 \mathrm{t} \mathrm{d}^{-1}$ from soil diffuse degassing processes was estimated. The gas source for Termas de Copahue, Las Máquinas, Las Maquinitas I and II is a 800$1000 \mathrm{~m}$ deep vapor zone with a temperature of $\sim 200-215^{\circ} \mathrm{C}$, as indicated by both the data of three deep wells drilled in the eighties SW of the natural degassing sites, and gas geothermometry. The occurrence of a unique gas zone feeding the manifestations of the area explains the remarkable compositional homogeneity of the fumaroles, with the exception of those discharging at Anfiteatro, where significant compositional and isotopic differences with respect to the other sites were observed. Using $\mathrm{CO}_{2}$ as a tracer of the original vapor phase, a natural thermal release of $\sim 77$ MW from Termas de Copahue, Las Máquinas, Las Maquinitas I and II was computed, and increases up to $\sim 107 \mathrm{MW}$ when the Anfiteatro degassing zone is considered.

The clear magmatic signature of the incondensable fumarolic gases, the wide expanse of the hydrothermal zones and the remarkable amount of gas and heat released by fluid expulsion, appear to be compatible with an active magmatic intrusion in the subsurface of this portion of the Caviahue caldera. This model well agrees with the proved 
occurrence of volcanic seismic tremor associated with the hydrothermal systems of the Copahue-Caviahue Volcanic Complex (Ibáñez et al., 2008; Forte et al., 2012).

\section{Acknowledgments}

The research leading to these results has received funding from the Deep Carbon Observatory under the DECADE research initiative (subcontract 10470-1145), from the projects UBACyT 01-W172 and UBACyT 20020120300077BA, PI UNRN 40-A-294 and PI UNRN 40-A-379. This paper benefitted from the useful and helpful comments of two anonymous reviewers who improved an early version of the manuscript.

\section{References}

Afanasyev, A.A., 2013. Multiphase compositional modelling of $\mathrm{CO}_{2}$ injection under subcritical conditions: the impact of dissolution and phase transitions between liquid and gaseous $\mathrm{CO}_{2}$ on reservoir temperature. Int. J. Greenhouse Gas Control 19, 731-742 (http://dx.doi.org/http://dx.doi.org/10.1016/j.ijggc.2013.01.042).

Agusto M. (2011). Estudio geoquímico de los fluidos volcánicos e hidrotermales del Complejo Volcánico Copahue Caviahue y su aplicación para tareas de seguimiento. Tesis Doctoral (unpublished). Universidad de Buenos Aires. 290 p.

Agusto, M., Varekamp, J., 2015. The Copahue Volcanic-Hydrothermal System and Applications for Volcanic Surveillance. In: En Tassi, F., Vaselli, O., y Caselli, A. (Eds.), Copahue Volcano. Springer International Publishing AG. ISBN: 978-3-662-48004-5.

Agusto, M., Caselli, A., Tassi, F., Dos Santos Alfonso, M., Vaselli, O., 2012. Seguimiento geoquímico de las aguas ácidas del sistema volcán Copahue-Río Agrio: posible aplicación para la identificación de precursores eruptivos. Rev. Asoc. Geol. Argent. 69 (4), 481-495.

Agusto, M., Tassi, F., Caselli, A., Vaselli, O., Rouwet, D., Capaccioni, B., Caliro, S., Chiodini, G. Darrah, T., 2013. Gas geochemistry of the magmatic-hydrothermal fluid reservoir in the Copahue-Caviahue Volcanic Complex (Argentina). J. Volcanol. Geotherm. Res. 257, 44-56.

Aiuppa, A., Tamburello, G., Napoli, R., Cardellini, C., Chiodini, G., Giudice, G., Grassa, F., Pedone, M., 2013. First observations of the fumarolic gas output from a restless caldera: implications for the current period of unrest (2005-2013) at Campi Flegrei. Geochemistry Geophysics Geosystems 14, 4153-4169.

Bermúdez, A., Delpino, D., López Escobar, L., 2002. Caracterización geoquímica de lavas y piroclastos holocenos del volcán Copahue, incluyendo los originados en la erupción del año 2000. Comparación con otros volcanes de la Zona Volcánica Sur de los Andes. XV Congreso Geológico Argentino, Calafate. Actas 1, pp. 377-382.

Berner, R.A., Lasaga, A.C., 1989. Modeling the geochemical carbon cycle. Sci. Am. 260, 74-81.

Bloomberg, S., Werner, C., Rissmann, C., Mazot, A., Horton, T., Gravley, D., Kennedy, B., Oze, C., 2014. Soil $\mathrm{CO}_{2}$ emissions as a proxy for heat and mass flow assessment, Taupo Volcanic Zone, New Zealand. Geochem. Geophys. Geosyst. 15, 4885-4904. http://dx.doi. org/10.1002/2014GC005327.

Burton, M.R., Sawyer, G.M., Granieri, D., 2013. Deep carbon emissions from volcanoes. Rev. Mineral. Geochem. 75, 323-354. http://dx.doi.org/10.2138/rmg.2013.75.11.

Cardellini, C., Chiodini, G., Frondini, F., 2003. Application of stochastic simulation to $\mathrm{CO}_{2}$ flux from soil: mapping and quantification of gas release. J. Geophys. Res. 108, 2425. http://dx.doi.org/10.1029/2002JB002165.

Caselli, A., Agusto, M., Fazio, A., 2005. Cambios térmicos y goequímicos del lago cratérico del volcán Copahue (Neuquén): posibles variaciones cíclicas del sistema volcánico. XVI Congreso Geológico Argentino. T1 pp. 751-756.

Caselli, A., Agusto, M., Velez, M.L., Forte, P., Bengoa, C., Daga, R., Albite, J.M., Capaccioni, B., 2015. The 2012 eruption. In: Tassi, F., Vaselli, O., Caselli, A. (Eds.), Copahue Volcano: The Smoking Mountain Between Argentina y Chile. Springer International Publishing AG (accepted for publication).

Chiodini, G., Granieri, D., Avino, R., Caliro, S., Costa, A., Werner, C., 2005. Carbon dioxide diffuse degassing and estimation of heat release from volcanic and hydrothermal systems. J. Geophys. Res. Solid Earth 110, B08204. http://dx.doi.org/10.1029/ 2004JB003542

Chiodini, G., Cioni, R., Guidi, M., Marini, L., Raco, B., 1998. Soil $\mathrm{CO}_{2}$ measurements in volcanic and geothermal areas. Appl. Geochem. 13, 543-552.

Chiodini, G., Frondini, F., Cardellini, C., Granieri, D., Marini, L., Ventura, G., 2001. $\mathrm{CO}_{2}$ degassing and energy release at Solfatara volcano, Campi Flegrei, Italy. J. Geophys. Res. Solid Earth 106, 16,213-16,221. http://dx.doi.org/10.1029/2001JB000246.

Chiodini, G., Baldini, A., Barbieri, F., Carapezza, M., Cardellini, C., Frondini, F., Granieri, D., Ranaldi, M., 2007. Carbon dioxide degassing at Latera caldera (Italy): evidence of geothermal reservoir and evaluation of its potential energy. J. Geophys. Res. http://dx.doi. org/10.1029/2006JB004896.

Chiodini, G., Caliro, S., Cardellini, C., Avino, R., Granieri, D., Schmidt, A., 2008. Carbon isotopic composition of soil $\mathrm{CO}_{2}$ efflux, a powerful method to discriminate different sources feeding soil $\mathrm{CO}_{2}$ degassing in volcanic-hydrothermal areas. Earth Planet. Sci. Lett. 274 (3-4), 372-379.

Chiodini, G., Vandemeulebrouck, J., Caliro, S., D' Auria, L., De Martino, P., Mangiacapra, A., Petrillo, Z., 2015. Evidence of thermal-driven processes triggering the 2005-2014 unrest at Campi Flegrei caldera. Earth Planet. Sci. Lett. 414, 58-67. http://dx.doi.org/10. 1016/j.epsl.2015.01.012.
Dellapé D., Pando G. (1975). Relevamiento geológico de la cuenca geotérmica de Copahue. Yacimientos Petrolíferos Fiscales. Unpublished Report No. 524, pp. 11.

Delpino, D., Bermúdez, A., 1993. La actividad del volcán Copahue durante 1992. Erupción con emisiones de azufre piroclástico. Provincia de Neuquén, Argentina. XII Congreso Geológico Argentino y II Congreso de Exploración de Hidrocarburos. Actas 4, pp. 292-301.

Delpino, D., Bermúdez, A., 2002. La erupción del volcán Copahue del año 2000. Impacto social y al medio natural $15^{\circ}$ Congreso Geológico Argentino. Actas 3, pp. 365-370.

DeMets, C., Gordon, R., Argus, F., Stein, S., 1994. Effect of recent revisions of the geomagnetic time scale on estimates of current plate motions. Geophys. Res. Lett. 21, 2191-2194.

Deutsch, C.V., Journel, A.G., 1998. Geostatistical Software Library and User's Guide. 2nd ed. Oxford University Press, New York.

Dionis, S.M., Melián, G., Rodríguez, F., Hernández, P., Padrón, E., Pérez, N., Barrancos, J., Padilla, G., Sumino, H., Fernandes, P., Bandomo, Z., Silva, S., Pereira, J., Semedo, H. 2015. Diffuse volcanic gas emission and thermal energy release from the summit crater of Pico do Fogo, Cape Verde. Bull. Volcanol. http://dx.doi.org/10.1007/s00445-0140897-4.

Folguera, A., Ramos, V., Hermanns, R., Naranjo, J., 2004. Neotectonics in the foothills of the Southernmost Central Andes $\left(37^{\circ}-38^{\circ} \mathrm{S}\right)$. Evidence of the strike-slip displacement along the Antiñir-Copahue fault zone. Tectonics 23 (TC 500823 pp.).

Folguera, A., Zapata, T., Ramos, V., 2006. Late Cenozoic extension and evolution of the Neuquén Andes. In: Kay, S., Ramos, V. (Eds.), Evolution of the Andean Margin: A Tectonic and Magmatic View from the Andes to the Neuquén Basin $\left(35^{\circ}-39^{\circ} \mathrm{S}\right)$. GSA Special Paper 407

Forte, P., Bengoa, C., Caselli, A., 2012. Análisis preliminar de la actividad sísmica del complejo volcánico Copahue-Caviahue mediante técnicas de array. $13^{\circ}$ Congreso Geológico Chileno, pp. 574-576 (acts).

Fridriksson, T., Kristjansson, B.R., Armannsson, H., Margretardottir, E., Olafsdottir, S. Chiodini, G., 2006. $\mathrm{CO}_{2}$ emissions and heat flow through soil, fumaroles, and steamheated mud pools at the Reykjanes geothermal area, SW Iceland. Appl. Geochem. 21, 1551-1569. http://dx.doi.org/10.1016/j.apgeochem.2006.04.006.

Gammoms, C.H., Wood, S.A., Pedrozo, F., Varekamp, J.C., Nelson, B., Shope, C.L., Baffico, G 2005. Hydrogeochemistry and rare earth element behavior in a volcanically acidified watershed in Patagonia. Argentina. Chem. Geol. 222, 249-267.

Giggenbach, W.F., 1975. A simple method for the collection and analysis of volcanic gas samples. Bull. Volcanol. 39 (1), 132-145.

Giggenbach, W.F., Goguel, R.L., 1989. Methods for the collection and analysis of geothermal and volcanic water and gas samples. Department of Scientific and Industrial Research, Chemistry Division, Reportp. 2401.

Giggenbach, W.F., Matsuo, S., 1991. Evaluation of results from Second and Third IAVCE field workshops on Volcanic gases, Mt. Usu, Japan, and White Island, New Zealand. Appl. Geochem. 6 (2), 125-141.

Granieri, D., Giovanni, C., Avino, R., Caliro, S., 2014. Carbon dioxide emission and heat release estimation for Pantelleria Island (Sicily, Italy). J. Vulcanol. Geotherm. Res. 275, 22-33. http://dx.doi.org/10.1016/j.jvolgeores.2014.02.011.

GVN, 2000a. Bulletin of the global volcanism network. Volcanic Activity Reports vol. 25 pp. $10-14\left(\mathrm{~N}^{\circ} 6\right)$.

GVN, 2000b. Bulletin of the global volcanism network. Volcanic Activity Reports vol. 25 pp. 1-3 ( $\left.\mathrm{N}^{\circ} 9\right)$.

Hernández, P.A., Pérez, N.M., Fridriksson, T., Egbert, J., Ilyinskaya, E., Thárhallsson, A. Ívarsson, G., Gíslason, G., Gunnarsson, I., Jónsson, B., 2012. Diffuse volcanic degassing and thermal energy release from Hengill volcanic system, Iceland. Bull. Volcanol. 74, 2435-2448.

Ibáñez, J.M., Del Pezzo, E., Bengoa, C., Caselli, A., Badi, G., Almendros, J., 2008. Volcanic tremor and local earthquakes at Copahue volcanic complex, Southern Andes, Argentina. J. Volcanol. Geotherm. Res. 174 (2008), 284-294.

JICA-EPEN (Japan International Cooperation Agency) (1992) The feasibility study on the Northern Neuquén Geothermal Development Project (Unpublished). Ente Provincial de Energía de la Provincia de Neuquén 89 p.

Jurío, R.L., 1977. Características geoquímicas de los fluidos termales de Copahue (Neuquén - Argentina). Principales implicancias geotérmicas. Minería 172 (11 pp.).

Latinoconsult, 1981. Estudio de Pospección Geotérmica en el área de Copahue. COPADE Neuquén.

Lavenu, A., Cembrano, J., 1999. Compressional and transpressional stress pattern for Pliocene and Quaternary brittle deformation in fore-arc and intra-arc zones (Andes of Central and Southern Chile). J. Struct. Geol. 21, 1669-1691.

Lewicki, J.L., Oldenburg, C.M., 2005. Near-surface $\mathrm{CO}_{2}$ monitoring and analysis to detect hidden geothermal systems. PROCEEDINGS, Thirtieth Workshop on Geothermal Reservoir Engineering. Stanford University SGP-TR-176.

Lewicki, J.L., Bergfeld, D., Cardellini, C., Chiodini, G., Granieri, D., Varley, N., Werner, C., 2005. Comparative soil $\mathrm{CO}_{2}$ flux measurements and geostatistical estimation methods on Masaya volcano, Nicaragua. Bull. Volcanol. 68 (1), 76-90.

Martini, M., Bermúdez, A., Delfino, D., Giannini, L., 1997. The thermal manifestation of Copahue volcano area. VIII Congreso Geológico Chileno, Antofagasta 4. Neuquen, Argentina, pp. 352-356.

Mas, G.R., Mas, L.C., Bengochea, L., 1996. Alteración ácido-sulfática en el Campo Geotérmico Copahue, Provincia del Neuquén. Asoc. Geol. Argent. 51 (1), 78-86.

Mas, L.C., Mas, G.R., Bengochea, L., 2000. Heatflow of Copahue geothermal field, its relation with tectonic scheme. Proceedings of World Geothermal Congress, Tohoku, Japan, pp. 1419-1424.

Mazot, A., Taran, Y., 2009. $\mathrm{CO}_{2}$ flux from the volcanic lake of El Chichón (Mexico). Geofís Int. 48 (1), 73-83.

Melnick, D., Folguera, A., Ramos, V.A., 2006. Structural control on arc volcanism: The Copahue-Agrio complex, South-Central Andes ( $37^{\circ} 50^{\prime}$ S). J. S. Am. Earth Sci. 22, 66-88. 
Naranjo, J.A., Polanco, E., 2004. The 2000 AD eruption of Copahue Volcano, Southern Andes. Rev. Geol. Chile 31 (2), 279-292.

Panarello, H., 2002. Características isotópicas y termodinámicas de reservorio del campo geotérmico Copahue-Caviahue, provincia del Neuquén. Rev. Asoc. Geol. Argent. 57 (2), 182-194.

Panarello, H., Levin, M., Albero, M.C., Sierra, J.L., Gingins, M.O., 1988. Isotopic and geochemical study of the vapor dominated geothermal field of Copahue (Neuquén, Argentina). Rev. Bras. Geofísica 5 (2), 275-282.

Polanco E. (2003). Evolución del volcán Copahue (37 45’ S), Andes del Sur. Tesis de Maestría (unpublished), Universidad Nacional Autónoma de México, 90 p.

Radic, J.P., 2010. Las cuencas cenozoicas y su control en el volcanismo de los complejos Nevados de Chillán y Copahue-Callaqui $\left(36^{\circ}-39^{\circ} \mathrm{S}\right)$. Andean Geol. 37 (1), 220-246.

Raich, J.W., Schlesinger, W.H., 1992. The global carbon dioxide flux in soil respiration and its relationship to vegetation and climate. Tellus 44B, 81-99.

Raich, J.W., Tufekcioglu, A., 2000. Vegetation and soil respiration: correlations and controls. Biogeochemistry 48 (1), 71-90.

Ramos, V.A., Folguera, A., 2000. Tectonic evolution of the Andes of Neuquén: constraints derived from the magmatic arc and foreland deformation. In: Veiga, G.D., Spalletti, L.A., Howell, J.A., Schwartz, E. (Eds.), The Neuquén Basin, Argentina: A Case Study in Sequence Stratigraphy and Basin Dynamics: Geological Society, London, Special Publications 252, pp. 15-35.

Rissmann, C. Christenson, B., Werner, C., Leybourne, M. Cole, J. Gravley, D. 2012. Surface heat flow and $\mathrm{CO}_{2}$ emissions within the Ohaaki hydrothermal field, Taupo Volcanic Zone, New Zealand. Appl. Geochem. 27, 223-239. http://dx.doi.org/10.1016/j apgeochem.2011.10.006.

Rojas Vera, E.A., Folguera, A., Zamora, Valcarce G., Giménez, M., Ruiz, F., Martínez, P., Bottesi, G., Ramos, V.A., 2010. Neogene to Quaternary extensional reactivation of a fold and thrust belt: the Agrio belt in the Southern Central Andes and its relation to the Loncopué trough $\left(38^{\circ}-39^{\circ} \mathrm{S}\right)$. Tectonophysics $92(1-4), 279-294$.

Sierra, J., D'Amore, F., Panarello, H., Pedro, G., 1990. Reservoir characteristics of the vapou dominatred geothermal field of Copahue, Neuquén, Argentina, as established by isotopic and geochemical techniques. Geothermal Investigations with Isotope and Geochemical Tecniques in Latin America. Final Proc. Nuclear Techniques in Geothermal Resources Investigation, San José, Costa Rica, pp. 13-30.
Sinclair, A.J., 1974. Selection of threshold values in geochemical data using probability graphs. J. Geochem. Explor. 3, 129-149.

Sierra, J., D'Amore, F., Panarello, H., Pedro, G., 1992. Reservoir characteristics of the vapour dominated geothermal field of Copahue, Neuquén, Argentina, as established by isotopic and geochemical techniques. Geothermal Investigations with Isotope and Geochemical Tecniques in Latin America. Final Proc. Nuclear Techniques in Geothermal Resources Investigation. San José, Costa Rica 13-30.

Tamburello, G. Agusto, M. Caselli, A Tassi, F, Vaselli, O Calabrese, S., Rouwet, D. Capaccioni, B., Cardellini, C., Chiodini, G., Di Napoli, R., Liccioli, C., Bitetto, M., Brusca, L., Bellomo, S., Aiuppa, A., 2015. Intense magmatic gas leakage through the Copahue crater lake. J. Geophys. Res. http://dx.doi.org/10.1002/2015JB012160 (in press).

Tassi, F., Agusto, M., Vaselli, O., Chiodini, G., 2015. Geochemistry of the magmatic-hydrothermal fluid reservoir of Copahue volcano (Argentina): insights from the chemical and isotopic features of fumarolic discharges. In: En Tassi, F., Vaselli, O., Caselli, A. (Eds.), Copahue Volcano: The Smoking Mountain Between Argentina y Chile. Springer International Publishing AG (accepted for publication).

Varekamp, J.C., 2008. The volcanic acidification of glacial Lake Caviahue, Province of Neuquen. Argentina 178, 184-196.

Varekamp, J.C., Ouimette, A.P., Herman, S.W., Flynn, K.D., Bermudez, A., Delpino, D., 2009. Naturally acid waters from Copahue volcano, Argentina. Applied Geochemistry 24, 208-220.

Varekamp, J.C., Ouimette, A., Hermán, S., Bermúdez, A., Delpino, D., 2001. Hydrothermal element fluxes from Copahue, Argentina: a "beehive" volcano in turmoil. Geology 29 (11), 1059-1062

Werner, C., Cardellini, C., 2006. Comparison of carbon dioxide emissions with fluid upflow, chemistry, and geologic structures at the Rotorua geothermal system, New Zealand. Geothermics 35, 221-238. http://dx.doi.org/10.1016/j.geothermics.2006. 02.006 .

Yuan, X., Asch, G., Bataille, K., Bock, G., Bohm, M., Echtler, H., Kind, R., Oncken, O., Wölbern, I., Yuan, X., Asch, G., Bataille, K., Bock, G., Bohm, M., Echtler, H., Kind, R., Oncken, O., Wölbern, I., 2006. Deep seismic images of the Southern Andes. In: Ramos VA, Kay S. (Ed.), Evolution of the Andean Margin: a Tectonic and Magmatic View from the Andes to the Neuquen Basin ( $\left.35^{\circ}-39^{\circ} \mathrm{S}\right)$. GSA Special Paper 407, pp. 61-72. 